\title{
Pengaruh Bukti Langsung, Kehandalan, Jaminan, Daya Tanggap dan Empati, Terhadap Kepuasan Pasien pada Puskesmas
}

\author{
Billy Rolly Sondakh \\ Johny R.E Tampi \\ Tinneke M. Tumbel \\ Jurusan Ilmu Administrasi, Program Studi Administrasi Bisnis \\ Fakultas Ilmu Sosial dan Politik.Universitas Sam Ratulangi \\ billysondakh08@gmail.com
}

\begin{abstract}
The goal of the study is to test the effects of efidence directly, reliability, asurance, response, empathy for the patient's satisfation at the medical center. The samples used in this study number one hundred. As for a sample method of taking by purposive sampling. The data analysis method used is quantitative analysis by using the validity test and reliability test, test $f$, determinative coefficient, test $t$ and regression analysis. Using multiple regression methods, you might conclude that the evidence variable immediately has a positive and significant impact on consumer satisfaction. Whereas reliability has a positive but insignificant effect on consumer satisfaction. Guarantee has a positive but insignificant effect on consumer satisfaction. The response has a positive but insignificant effect on consumer satisfaction. For empathy, it has no positive or insignificant impact on consumer satisfaction. Simultaneous evidence of direct,reliability can signifikantly affect costumers satisfaction with $f$ counts greater than the significance number. The resulting coefficient determination is 0.322 which means 32.2 percent of variable changes in consumer satisfaction are explained by common evidence, reliability, guarantees, response and empathy changes, while 67.8 percent is explained by other non-research variables.
\end{abstract}

Keyword :direct efidence, directly, reliability, asurance response, empathy

\section{Pendahuluan}

Pada dasarnya keadaan sehat adalah kehendak semua pihak.Tidak hanya oleh orang per orang, tetapi juga oleh keluarga, kelompok dan bahkan masyarakat.Dalam rangka mewujudkan status kesehatan masyarakat yang optimal, maka berbagai upaya harus dilaksanakan, salah satu di antaranya ialah menyelenggarakan pelayanan kesehatan. Penyelenggaraan pelayanan kesehatan untuk masyarakat di tingkat dasar di Indonesia adalah melalui Pusat Kesehatan Masyarakat (Puskesmas) yang merupakan unit organisasi fungsional

Dinas Kesehatan Kabupaten/ kecamatan yang diberi tanggung jawab sebagai pengelola kesehatan bagi masyarakat tiap wilayah dari kabupaten atau kecamatan bersangkutan. Pada era globalisasi, dinamika kehidupan dunia usaha semakin keras dan ketat termasuk di bidang pelayanan kesehatan dalam hal ini 
puskesmas. Dengan makin tingginya tingkat pendidikan dan keadaan sosial ekonomi masyarakat, maka kebutuhan dan tuntutan masyarakat akan kesehatan tampak makin meningkat pula.Untuk dapat memenuhi kebutuhan dan tuntutan tersebut, tidak ada upaya lain yang dapat dilakukan, kecuali menyelenggarakan pelayanan kesehatan yang sebaik -baiknya. Sebagai lembaga kesehatan yang bermisi meningkatkan derajat kesehatan masyarakat, Puskesmas ini telah berperan dalam memelihara dan meningkatkan derajat kesehatan masyarakat. Kepercayaan yang diberikan masyarakat dan pemerintah terhadap Puskesmas tersebut adalah sebuah kehormatan sekaligus amanat dan tugas berat yang harus dipikul dengan sungguhsungguh dan hati penuh. Adanya bentuk pelayanan kesehatan yang diberikan oleh Puskesmas ini diharapkan pasien akan dapat memberikan penilaian tersendiri terhadap Puskesmas tersebut. Jika pelayanan yang diberikan sesuai dengan yang dikehendaki, maka pasien akan puas, jika yang terjadi sebaliknya maka akan menyebabkan kehilangan minat pasien untuk berobat dan ini akan menyebabkan pasien mempunyai image negatif terhadap Puskesmas tersebut, yang akan mengakibatkan menurunnya jumlah pasien akhirnya akan menyebabkan pengurangan keuntungan. Apalagi banyaknya puskesmas yang ada di minahasa selatan menyebabkan Puskesmas motoling barat harus punya strategi pemasaran yang tepat. Dalam lingkungan global yang semakin ketat dengan masuknya pelayanan yang inovatif di pasaran disatu sisi dan kondisi pasar yang jenuh untuk pelayanan-pelayanan yang monoton disisi lain mengelola loyalitas pasien menjadi tantangan manajerial Puskesmas.

Menurut Kotler dan Keller (2009) pemasaran adalah fungsi suatu organisasi dan sesuatu kegiatan proses untuk menciptakan, mengkomonikasikan, dan memberikan nilai kepada pelanggan dan untuk melakukan atau mencari hubungan pelanggan dengan cara yang menguntungkan bagi organisasi dan pelaku pelaku kepentingannya.

Pemasaran adalah sala satu kegiatan atau faktor penting dalam suatu organisasi. Dimana Suatu siklus akan berakhir apabila konsumen merasa puas terhadap pemilikan suatu barang atau jasa. Siklus ini akan terjadi secara berulang-ulang atau terusmenerus.Kegiatan pemasaran harus dapat memberikan kepuasan kepada konsumen jika menginginkan usahanya berjalan terus menerus atau konsumen mempunyai pandangan yang baik terhadap perusahaannya.

Dimana pemasaran bukan hanya sekedar suatu cara sederhana untuk 
memaksimalkan target dari kegiatan penjualan (karena penjualan hanya merupakan suatu tahap dari proses pemasaran), melainkan pemasaran juga dilakukan sebelum maupun sesudah kegiatan penjualan.

\section{Konsep Pemasaran}

Falsafah konsep pemasaran bertujuan memberikan kepuasan terhadap keinginan dan kebutuhan konsumen atau pasien puskesmas. Menurut swastha dan irawan,(2005) mendefinisikan konsep pemasaran sebua falsafah bisnis yang menyatakan bahwa pemuasan kebutuhan konsumen merupakan syarat ekonomi dan sosial bagi kelangsungan hidup perusahaan. Bagian pemasaran pada suatu perusahaan memegang peranan yang sangat penting dalam rangka mencapai besarnya volume penjualan, karena dengan tercapainya sejumlah volume penjualan yang diinginkan berarti kinerja bagian pemasaran dalam memperkenalkn prduk telah berjalan dengan benar penjualan dan pemasaran sering diangap sama tetapi sebenarnya berbeda. Tujuan utama konsep pemasaran adalah melayani konsumen dengan mendapatkan sejumlah laba, atau dapat di artikan sebagai perbandingan Antara penghasilan drngan biaya yang layak. Ini berbeda dengan konsep penjualan yang menitipberatkan pada keinginan perusahaan falsafah dalam pendekatan penjualan adalah memprduksi sebuah pabrik, kemudian meyakinkan konsumen agar bersediah membelinya. Sedangkan pendekatan kosep pemasaran mengkehendaki agar manajemen menentukan keinginan konsumen terlebih dahulu, setelah itu baru melakukan bagaimana caranya memuaskan.

\section{Pengertian Pelayanan}

Pelayanan ialah menolong untuk menyediakan sesuatu yang di perlukan oleh orang lain diantaranya adalah pembeli. Pelayanan dapat di berikan kepada orang lain sebagai pertolongan yang di butukan orang lain itu sendiri. Yang mana dengan pertolongan tersebut dapat membantu orang lain untuk dapat mengatasi masalanya.

Menurut Tjiptono, Fandi. 2014 variabel Bukti langsung berkenaan dengan penampilan fisik fasilitas layanan, peralatan, sumber daya manusia, danmateri komunikasi perusahaan. Keandalan merupakan kemampuan perusahaan untuk memberikan pelayanan yang dijanjikan dengan akurat sejak pertama kali. Daya tanggap berkenaan dengan kesediaan dan kemampuan penyedia layanan untuk membantu para pelanggan dan merespon permintaan mereka dengan segera. Jaminanmerupakan Pengetahuan dan kesopanan para karyawan serta kemampuan 
mereka menumbuhkan rasa percaya (trust) dan kepercayaan pelanggan(confidence). Empati merupakan kemampuan memahami masalah pelanggannya bertindak demi kepentingan pelanggan, dan memberikan yang diharapkan. Kepuasan pelanggan adalah perasaan senang atau kecewa seseorang yang muncul setelah membandingkan antara kinerja (hasil) produk yang dipikirkan terhadap kinerja yang diharapkan

\section{Prilaku Konsumen}

Seiring dengan meningkatnya pertumbuhan ekonomi di Indonesia saat ini, maka masyarakat semakin pandai menyeleksi barang dan jasa yang akan dikonsumsi. Oleh karena itu agar puskesmas dapat mengembangkan usahanya maka ia harus mengetahui perilaku konsumen sehingga kehadiran pelanggan dapat terjaga. Sikap dan perilaku konsumen akan mempunyai pengaruh yang cukup besar dalam menentukan suatu strategi bagi suatu perusahaan. Menurut Hasan (2013), perilaku konsumen adalah studi prses yang terlibat ketika individu atau kelompok memilih, membeli, mengunakan atau mengatur produk, jasa,ideal atau pengalaman untuk memuaskan kebutuhan dan keinginan konsumen.
Sedangkan menurut Engel dan Blackwell (2013), Perilaku konsumen adalah sebagai tindakan yang langsung terlibat dalam mendapatkan, mengkonsumsi, dan menghabiskan produk dan jasa, termasuk proses yang mendahului dan menyusuli tindakan ini.

\section{Indikator kepuasan konsumen}

Menurut kotler (2005) beberapa pelanggan menyukai produk kita dan setelah digunakan mereka mengucapkan kata-kata yang baik untuk produk. Tetapi ada orang menggunakan produk itu , dan membicarakan hal-hal yang tidak baik dari mulut ke mulut mengenai produk yang kita jual. kepuasan pelanggan sangat penting bagi setiap organisasi, baik sector jasa maupun sector barang oleh karena itu tidak setiap waktu produsen dapat memuaskan pelanggan.Karena ada begitu banyak pelanggan yang menggunakan produk dan setiap pelanggan menggunakannya secara berbeda sikap yang berbeda dan berbicara secara berbeda.Yang paling bahaya adalah ketika pelanggan berbicara dari mulut ke mulut.

\section{Metode Penelitian}

Penelitian ini di lakukan pada puskesmas motoling barat di desa raanan baru. Jenis penelitian yang digunakan adalah statistik deskriptif. Menurut 
Sugiyono(2012) statistik deskriptif adalah: "Statistik yang digunakan untuk menganalisis data dengan cara mendeskripskan atau menggambarkan data yangtelah terkumpul sebagaimna adanya tanda bermaksud membuat kesimpulan yang berlaku secara umum atau generalisasi. Adapun jenis data yang digunakan dalam uraian ini adalah sebagai berikut: data kuantitatif dan sumber data. Data merupakan faktor yang penting untuk menunjang suatu penelitian.Data penting yang diperlukan dalam penelitian ini bersumber pada responden dimana data tersebut diperoleh melalui penyebaran kuesioner terhadap pasien Puskesmas.Berdasarkan sumbernya data dapat dikelompokkan menjadi data primer dan data sekunder.

Data primer adalah data yang pertama kali di catat dan dikumpulkan oleh peneliti (Sanusi, 2011:). Data primer dalam penelitian ini diperoleh dengan menyebarkan kuesioner kepada responden, yaitu masyarakat, yang datang ke Puskesmas kecamatan motoling barat. Dengan memberitahukan kepada responden tujuan dan maksud serta cara pengisian daftar pertanyaan, diharapkan responden dapat mengisi pertanyaan dengan baik dan benar.

(Sekaran 2011) data sekunder adalah data yang mengacu pada informasi yang dikumpulkan dari sumber yang telah ada. Sumber data sekunder adalah catatan atau dokumentasi perusahaan, internet, situs Web dan lainnya.

Uji validitas Sugiyono (2013) mendefinisikan validitas sebagai suatu ukuran yangmenunjukan tingkat keabsahan atau kesahihan suatu instrument. Validitas menunjukan sejauh mana alat ukur itu dapat mengukur apa yang dapat diukur. Valid tidaknya suatu alat ukur tergantung pada mampu atau tidaknya alat ukur tersebut mencapai yang dikehendakinnya dengan tepat, karena alat ukur yang kurang valid menunjukan bahwa tingkat validitasnya rendah. Uji validitas pada penelitian ini dilakukan dengan bantuan SPSS 25.Menurut Sekaran (2006), apabila hasil model analisis faktor menunjukan bahwa dengan signifikan dibawah 0.05 dan Kaiser-Mayer-Olkin (KMO), antiimage, dan factor loading $\geq 0.5$ maka dinyatakan valid dan sampel bisa diteliti lebih lanjut.

Uji reliabel Uji reliabilitas digunakan untuk menunjukan sejauh mana alat pengukur yang digunakan dapat di percaya atau dilakukan untuk mengetahui konsistensi dan ketepatan pengukuran. Uji reliabilitas dalam penelitian ini menggunakan koefisien Croanbach's Alpa, dengan bantuan SPSS25. Sugiyono (2013) mengemukakan pengujian reliabilitas ditunjukan oleh koefesien Croanbach's 
Alpadan dapat diolah dengan bantuan SPSS25. Apabila ada pernyataan yang memiliki nilai Croanbach's Alpa if item deleted lebih besar dari pada Croanbach's Alpa maka pernyataan tersebut tidak reliable dan harus dilakukan pengujian selanjutnya.

Analisis ini digunakan untuk mengetahui bagaimana penilaian pasien tentang kualitas pelayanan terhadap kepuasaan pasien pada Puskesmas kecamatan motoling barat.Analisis yang digunakan meliputi pengujian terhadap bukti langsung, kehandalan, jaminan, daya tanggap, empati, dan kepuasan konsmen.Model analisis yang digunakan adalah analisis regresi berganda.Model regresi digunakan untuk mengansumsikan bahwa terdapat hubungan linear antara variabel kualitas pelayanan terhadap kepuasan pasien.Jadi analisis regresi berganda dilakukan jika jumlah variabel independennya minimal dua (Sugiyono, 2010).

\section{Hasil Penelitian}

Berdasarkan hasil dari uji validitas bahwa Jika skor item tersebut berkorelasi positif dengan skor total skor item dan lebih tinggi dari korelasi antar item, menunjukkan kevalidan instrumen tersebut. Maka dinyatakan bahwa bukti langsung, kehandalan, jaminan, daya tanggap,empati, dan kepuasan konsumen $\mathrm{R}$ hitung lebih tinggi dari $\mathrm{R}$ tabel maka hasil dari uji validitas ini dinyatakan valid.

Berdasarkan hasil dari uji realibel Tingkat reliabilitas suatu konstruk / variabel penelitian dapat dilihat dari hasil statistik Cronbach Alpha $(\alpha)$ Suatu variabel dikatakan reliable jika memberikan nilai cronbach alpha > 0,60 (Ghozali, 2005). Dari pernyataan ini maka dapat di lihat bahwa semua pernyataan pada kuesioner dinilai reliabel karena nilai Nilai Cronbach's Alpha Based on Standardized Item pada setiap variabel > 0,60 maka hasil uji t pada penelitian ini dapat dijelaskan sebagai berikut:

Variabel Bukti Langsung

Hipotesis variabel bukti langsung adalah:

- $\mathrm{H}_{0}: \beta=0$, variabel bukti langsungtidak mempunyai pengaruh yang signifikan secara parsial terhadap variabel kepuasan konsumen.

- $\mathrm{H}_{0}: \quad \mathrm{B}=0$, variabel bukti langsungmempunyai pengaruh yang signifikan secara terhadap variabel kepuasan konsumen

Pada variabel bukti langsung dengan tingkat signifikansi95\% (a =0,05). Angka signifikansi (P Value) pada variabel bukti langsung sebesar $0,003<0,05$. Atas dasar perbandingan tersebut, maka $\mathrm{H}_{0}$ ditolak atau berarti variabel bukti langsung 
mempunyai pengaruh yang signifikan

terhadap variabel kepuasan konsumen.

Variabel Kehandalan

Hipotesis variabel kehandalan adalah:

- $\mathrm{H}_{0}: \beta=0$, variabel kehandalantidak mempunyai pengaruh yang signifikan secara parsial terhadap variabel kepuasan konsumen.

- $\mathrm{H}_{0}: \quad \mathrm{B}=0, \quad$ variabel kehandalanmempunyai pengaruh yang signifikan secara parsial terhadap variabel kepuasan konsumen

Pada variabel kehandalan dengan tingkat signifikansi $95 \% \quad(\mathrm{a}=0,05) . \quad$ Angka signifikansi (P Value) pada variabel kehandalan sebesar 0,286 >0,05. Atas dasar perbandingan tersebut, maka $\mathrm{H}_{0}$ diterima atau berarti variabel kehandalan tidak mempunyai pengaruh yang signifikan terhadap variabel kepuasan konsumen.

Variabel Jaminan

Hipotesis variabel jaminan adalah:

- $\mathrm{H}_{0}: \beta=0$, variabel jaminantidak mempunyai pengaruh yang signifikan secara parsial terhadap variabel kepuasan konsumen.

- $\quad \mathrm{H}_{0}: \beta=0$, variabel jaminanmempunyai pengaruh yang signifikan secara parsial terhadap variabel kepuasan konsumen Pada variabel jaminan dengan tingkat signifikansi $95 \% \quad(\mathrm{a}=0,05) . \quad$ Angka signifikansi (P Value) pada variabel kehandalan sebesar 0,327 >0,05. Atas dasar perbandingan tersebut, maka $\mathrm{H} 0$ diterima atau berarti variabel jaminan tidak mempunyai pengaruh yang signifikan terhadap variabel kepuasan konsumen.

Variabel Daya Tanggap

Hipotesis variabel daya tanggap adalah:

- $\mathrm{H}_{0}: \beta=0$, variabel daya tanggaptidak mempunyai pengaruh yang signifikan secara parsial terhadap variabel kepuasan konsumen.

- $\mathrm{H}_{0}: \boldsymbol{\beta}=0$, variabel daya tanggap mempunyai pengaruh yang signifikan secara parsial terhadap variabel kepuasan konsumen

Pada variabel daya tanggap dengan tingkat signifikansi 95\% (a =0,05). Angka signifikansi ( $\mathrm{P}$ Value) pada variabel daya tanggap sebesar 0,379 >0,05. Atas dasar perbandingan tersebut, maka $\mathrm{H}_{0}$ diterima atau berarti variabel daya tanggap tidak mempunyai pengaruh yang signifikan terhadap variabel kepuasan konsumen.

Variabel Empati

Hipotesis variabel empati adalah:

- $\mathrm{H}_{0}: \mathrm{B}=0$, variabel empatitidak mempunyai pengaruh yang signifikan secara

parsial terhadap variabel kepuasan konsumen.

- $\mathrm{H}_{0}: \beta=0$, variabel empatimempunyai pengaruh yang signifikan secara parsial terhadap variabel kepuasan konsumen 
Pada variabel empati dengan tingkat signifikansi95\% (a $=0,05)$. Angka signifikansi (P Value) pada variabel empati sebesar 0,785>0,05. Atas dasar perbandingan tersebut, maka $\mathrm{H}_{0}$ diterima atau berarti variabel empati tidak mempunyai pengaruh yang signifikan terhadap variabel kepuasan konsumen. Dari hasil uji $\mathrm{F}$ pada penelitian ini didapatkan nilai $\mathrm{F}$ hitung sebesar 10,411 dengan angka signifikansi ( $\mathrm{P}$ value) sebesar 0,000. Dengan tingkat signifikansi 95\% $(\mathrm{a}=0,05)$. Angka signifikansi ( $\mathrm{P}$ value) sebesar $0,000<0,05$. Atas dasar perbandingan tersebut, maka $\mathrm{H}_{0}$ ditolak atau berarti variabel bukti langsung, kehandalan, jaminan, daya tanggap dan empati mempunyai pengaruh yang signifikan secara bersama-sama terhadap variabel kepuasan konsumen.

\section{Pembahasan}

Bukti langsung berpengaruh positif dan signifikan terhadap kepuasan konsumen.

Pernyataan hipotesis pertama bahwa Bukti langsung berpengaruh positif dan signifikan terhadap kepuasan konsumen terbukti. Hal ini dapat ditunjukkan dengan nilai signifikansi yang lebih kecil dari nilai koefisien regresi. Dapat disimpulkan bahwa semakin tinggi bukti langsung yang diberikan Puskesmas ke pasien, maka akan semakin tinggi pula kepuasan konsumennya.

bukti langsung berpengaruh positif dan signifikan dari bukti langsung ini yang mencakup penampilan fisik, perlengkapan pegawai, dan sarana komunikasi puskesmas motoling barat lebi lagi mengoptimalkan atau mengutamakan bukti langsung demi kepuasan pasien.

Kehandalan berpengaruh positif dan signifikan terhadap kepuasan konsumen.

kehandalan berpengaruh positif dan signifikan terhadap kepuasan konsumen tidak terbukti. Hal ini dapat ditunjukkan dengan nilai signifikansi yang jauh diatas koefisien regresi. Dapat disimpulkan bahwa kehandalan berpengaruh positif tetapi tidak signifikan terhadap kepuasan konsumen.

kehandalan membrikan pelayanan yang profesionanal serta akurat dan memuaskan bagi kepuasan pasien.

Jaminan berpengaruh positif dan signifikan terhadap kepuasan konsumen.

Pernyataan hipotesis ketiga bahwa jaminan berpengaruh positif dan signifikan terhadap kepuasan konsumen tidak terbukti. Hal ini dapat ditunjukkan dengan nilai signifikansi yang jauh diatas nilai koefisien regresi. Dapat disimpulkan bahwa jaminan berpengaruh positif tetapi tidak signifikan terhadap kepuasan konsumen.

Dari pernyataan jaminan ini telah memberikan rasa aman danterjaminnya 
pasien melakukan pengobatan sehingga dapat menumbukan rasa keprcayaan untuk cepat sembu kepada pasien.

Daya Tanggap berpengaruh positif dan signifikan terhadap kepuasan konsumen.

Pernyataan hipotesis keempat bahwa daya tanggap berpengaruh positif dan signifikan terhadap kepuasan konsumen tidak terbukti. Hal ini dapat ditunjukkan dengan nilai signifikansi yang jauh diatas nilai koefisien regresi. Dapat disimpulkan bahwa jaminan berpengaruh positif tetapi tidak signifikan terhadap kepuasan konsumen.

Pernyataan ini daya tanggap mampu menujukan rasa kepercayaan untuk memberikan pelayanan yang optimal kepada pasien dengan tanggap. Empati berpengaruh positif dan signifikan terhadap kepuasan konsumen.

Pernyataan hipotesis ini menyatakan bahwa berpengaruh positif dan signifikan terhadap kepuasan konsumen tidak terbukti. Hal ini dapat ditunjukkan dengan nilai signifikansi yang jauh diatas nilai koefisien regresi. Dapat disimpulkan bahwa empati tidak berpengaruh positif dan juga tidak signifikan terhadap kepuasan konsumen.

Untuk empati meliputi kemudahan dalam melakukan hubungan, komunikasi yang baik untuk memberikan perhatian terhadap setiap pasien serta pengertian terhadap keluhan keluhan pasien sehingga tercapai kepuasan pasien.

Dari variabel bukti langsung, kehandalan, daya tanggap, jaminan dan perhatian, variabel bukti langsung yang paling berpengaruh dominan terhadap kepuasan pasien Dimana variabel bukti langsung ini mempunyai pengaruh yang positif dan signifikan. Faktor kehandalan, daya tanggap, jaminan mempunyai pengaruh positif tetapi tidak signifikan. Sedangkan faktor empati menurut hasil penelitian ini tidak berpengaruh positif dan juga tidak signifikan terhadap kepuasan konsumen.

Penelitian ini menemukan bahwa variabel Bukti langsung berpengaruh positif dan signifikan terhadap kepuasan konsumen terbukti. ini dapat ditunjukkan dengan nilai signifikansi (P Value) yang lebih kecil dari nilai koefisien regresi Dapat disimpulkan bahwa semakin tinggi bukti langsung yang diberikan Puskesmas ke pasien, maka akan semakin tinggi pula kepuasan konsumennya.

Penelitian ini menemukakan bahwa variabel kehandalan berpengaruh positif tetapi tidak signifikan dengan nilai signifikan jauh di atas dari nilai koefesiensi regresi. Dapat disimpulkan bahwa kehandalan berpengaruh positif tetapi tidak signifikan terhadap kepuasan konsumen. 
Penelitian ini menemukakan bahwa Variabel jaminan berpengaruh positif tetapi tidak signifikan dengan nilai signifikan jauh di atas dari nilai koefesiensi regresi. Dapat disimpulkan bahwa jaminan berpengaruh positif tetapi tidak signifikan terhadap kepuasan konsumen.

Penelitian ini menemukakan bahwa Variabel daya tanggap berpengaruh positif tetapi tidak signifikan dengan nilai signifikan jauh di atas dari nilai koefesiensi regresi. Dapat disimpulkan bahwa jaminan berpengaruh positif tetapi tidak signifikan terhadap kepuasan konsumen.

Sedangkan variabel empati tidak berpengaruh positif dan juga tidak signifikan terhadap kepuasan konsumen. Hal ini dapat ditunjukkan nilai signifikan jauh di atas dari nilai koefesiensi regresi. Dapat disimpulkan bahwa empati tidak berpengaruh positif dan juga tidak signifikan terhadap kepuasan konsumen.

\section{Simpulan}

Dengan mempertimbangkan realita kebutuhan konsumen maka Puskesmas kecamatan motoling barat perlu meningkatkan aspek bukti langsung kondisi gedung Puskesmas, peralatan pendukung untuk melakukan pemeriksaan pasien, ruang tunggu yang disediakan oleh Puskesmas, penampilan dan kondisi setiap ruangan Puskesmas. Memberikan
Kehandalan dan tindakan pelayanan yang akurat oleh tenaga medis Puskesmas, profesionalisme dalam menangani keluhan pasien oleh para tenaga medis Puskesmas, melayani dengan baik dan ramah saat melakukan pengobatan dan perawatan, memberikan pelayanan dengan tepat dan benar sesuai dengan prosedur yang ditetapkan dalam dalam memberikan pelayanan selalu sesuai dengan jadwal yang telah ditetapkan. Memberikan Jaminan rasa aman dan terjaminnya pasien pada saat melakukan pengobatan atau perawatan, dapat menumbuhkan rasa kepercayaan untuk cepat sembuh kepada pasien, petugas berpengalaman dan terlatih dalam melakukan pengobatan dan mampu mengatasi keluhan dengan cepat mengenai kondisi kesehatan pasiennya. Untuk Empati pelayanan,harus memberikan keramahan yang sama tanpa memandang status pasien, dapat memberikan perhatian kepada setiap pasiennya, pengertian terhadap keluhankeluhan pasiennya. Dalam memberikan pelayanan kepada pasien sehingga akan tercapai kepuasan daripasien.

\section{Referensi}

Anwar, S. (2011). Metode Penelitian Bisnis, Salemba Empat Jakarta.

Kotler dan Keller. (2009). Manajemen Pemasaran. Jakarta: Erlangga. 
Kotler and Armstrong. (2008) PrinsipPrinsip Pemasaran. Terjemahan Damos Sihombing. Principles of marketing. 1999. Jakarta: Erlanga.

Rao Purba, (2006), Measuring Consumer Perception Through Factor Analysis, The Asian Manager (February-March).

Sugiyono. (2013) Metode Penelitian Pendidikan Pendekatan Kuantitatif, Kualitatif, dan $R \& D$. bandung: Alfabeta.

Swastha, B. \& Irawan. (2005). Manajemen Pemasaran Modern, libertyYogyakarta.

Sekaran, U. 2011. Research Methods for business. Jakarta: SalembaEmpat.

Sekaran, U. (2006). Metodologi Penelitian Untuk Bisnis buku 1 edisi 4, jakarta : Salemba Empat

Tjiptono, Fandi (2014) Pemasaran Jasa, cetakan ke-4 yogyakarta: c.v andi offset. 